Sochety of PUBhic ANalysts and other ANalytical Chemists (joint meeting with the FOOD GROUP OF THE SOCIETY OF CHFMICAL INDUSTRY, at the Chemical Society, Burlington House, Piccadilly, London, W.1), at 7 p.m.-Discussion on "The Occurrence, Physiological Importance and Fstimation of Metallic Contaminants in Foodstuffs".

\section{Thursday, December 4}

CHEMTCAL SOCTETY, SHEFFTELD SECTION (joint meeting with the SAEFFIHLI UNIVERSiTy CHxMICAI SocIETY, in the Chemistry Lecture Theatre, The University, Shcffield), at 5.30 p.m.- Prof. G. R. Clemo,
F.R.S.: "The Bearing of the Isotopes of Carbon, Hydrogen, Oxygen F.R.S.: "The Bearing of the Isotopes

INSTITUTION OF ELECTRICAL ENGINEERS (joint meeting with the ACOUstics GROUP OF THE PHysical SocieTy, at Savoy Place, Victoria Embankment, London, W.C.2), at 5.30 p.m.-Dr. W. G. Radley "Speech Communication under Conditions of Deafness or Loud Noise".

Chemicar Socrety Notmingham Section (in the Chemistry Lecture Theatre, University College, Nottingham), at $6 \mathrm{p.m}$ - Scientifle Papers. ILIUMTNATING ENGINEREING SOCIETY, MANCHESTER CENTRE (in the Reynolds Hall, College of Technology, Manchester), at 6 p.m.-Mr. W. Imrie-Smith : Industrial Iighting.

InstiTutron OF MECHANIOAT ENGINRER, GRADUATES' SECTION (at Storey's Gate, St. James's Park, London, S.W.1), at 6.30 p.m.Chrmroar Sochwty (at Burlington House, Piccadilly, London, W.1), at 7.30 p.m.-Sir Ian Heilbron, F.R.S.: "Recent Developments in the Vitamin A Field"s (Pedler Lecture).

SOCIETY OF Chlmical INDUSTRY, CHemical ENGINEERING GROUP (joint meeting with the BRISTOL SECTION of the SocIETY OF CHEMICAI INDUSTRY, at Bristol).-Mr. A. Forster and co-authors : "The Manufacture of Tetryl by Continuous Nitration".

Friday, December 5

Instumution of Electrical Enginkers, Measdriments Section (at Savoy Place, Vlictoria Fmbankment, London, W.C.2), at $5.30 \mathrm{p} \cdot \mathrm{m}$. -Discussion on "Economics of Metering" (to be opened by Mr. M. Whitehead).

Institution of Mechanical Engingers (at Storey's Gate, St. James's Park, London, S.W.1), at 5.30 p.m.-Dr. E. A. Watson:

"Fuel and Combustion 'Systems for the Aero Gas Turbine".

Gyologists' Assoctation (at the Geological Society of London, Burlington House, Piccadilly, London, W.1), at 6 p.m.-Prof. D. M. S. Watson, F.R.S.: "Fossllization",

ROYAI STATISTICAL SOCTRTY, INDTSTRIAT APPIIOATIONS SRCTION (at the E.L.M.A. Lighting Service Bureau, 2 Savoy Hill, London, W.C.2), at 6 p.m.Mr. E. C. Fieller: "The Mathematics Division
of the National Physical Laboratory, with particular reference to Statistical Methods".

Society of Chemical Industry, Manchester Section (joint meeting with the LOCAL SECTYONS of the CHEMrCAL SOCIETY and the ROYAL INSTITUTE OF CHRMTSTRY, in the Lecture Hall, Albert Hall, Manchester), at 6.30 p.m.-Sir Wallace Akers: "Industrial Uses of Atomic Energy".

MANCHESTER STATTSTICAI SOcIETy, IndUStriat Grodp (in the Society of Architects' Room, Textile Institute, 16 St. Mary's Parson age, Manchester), at 6.45 p.m.-Mr. J. Morley : "Some Statistica xperiments in the steel Industry

SOCIETY OF INSTRUMENT TECHNOLOGY, MIDLAND SECTION (at the Chamber of Commerce Buildings, New Street, Birmingham), at 7 p.m. Mr. V. A. H

\section{Saturday, December 6}

British Mrcologicat Society (at the Linnean Society of London Burlington House, Piccadilly, London, W.1), at 12 noon-Annual Meeting; at 2 p.m.-Prof. C. G. C. Chester

ROXAL INSTITUTE OF CHEMISTRY, LONDON AND SOUTH-EASTERN CoUNTIRs SECTION (at the University, Reading), at 3 p.m.-Prof. E. A. Guggenheim, F.R.S.: "The Atomic Nucleus".

\section{APPOINTMENTS VACANT}

APPLICATIONS are invited for the following appointments on or before the dates mentioned:

ASSISTANT IN THE CHEMISTRY DEPARTMENT-The Secretary, Royal Dick) Veterinary College, Summerhall, Edinburgh 9 (December 1). ASSISTANT LABORATORY TEOHNICIAN IN THE HISTOLOGICAL LABORATORY - The Registrar, The University, Liverpool (December 6).

CHEMICAI PATHOLOGIST in the Department of Pathology and Bacteriolngy-The Secretary, Welsh National School of Medicine,
10 The Parade, Cardiff (December 6). TECHNICAL ASSISTANTS IN THE PASTURE RESEARCH BRANCH of the
Department of Agriculture and Lands-The Office of the High Commissioner for Southern Rhodesia, 429 Strand, London, W.C.2 (December 10).

ADVISORY OFFICER IN CROP HUSBANDRY-The Sccretary, West of Scotland Agricultural College, 6 Blythswood Square, Glasgow, C. (December 12).

ALGOLOGIST (Scientific Officer) at the Millport Laboratory-The

Secretary, Scottish Marine Biological Association, 185 St. Vincent Secretary, Scottish Marine Biological
Street, Glasgow, C.2 (December 13).
SEnIor Physicist with experience in textile research, a SENIOR Oraninio Chemist with experience in textile research, a PHysicist with research experience, though not necessarily in textiles, and a CHEMrst for physical chemical research-The Director of Research, British Jute Trade Research Association, Bellfldd Street, Dundee
(December 20).

JUNIOR OBSERVER-The Director, The Observatories, Cambridge December 20)

ASSISTANT POMOLOgIST, and an ASSISTAN'T PLANT PHYSIOLOGIST, at the Long Ashton Research Station-The Secretary and Registrar, The University, Bristol (December 27).

NATURALIST at the Dove Marine Laboratory-The Registrar, King's College, Newcastle-upon-Tyne (December 31).

TRAVIS RESEARCH FELLOWSHIP IN BAOTERIAL METABOIISM in the Medical School, University of Otago-The High Commissioner for New Zealand, 415 Strand, London, W.C.2 (Otago, December 31).

RESEARCH FELLOWSHIP for the study of properties of natural and synthetic flbres-The Registrar, The University, Leeds 2 (January 1). HEAD OF THE APPLIWD NUTRITION DEPARTMENT-The Secretary, Rowett Rescarch Institute, Bucksburn, Aberdeenshire (January 3). ASSISTANT LECTURER (Grade III) FOR THE DEPARTMENT OF BREWING AND InDUSTRIAL FERmentation-The Secretary, The University, Edmund Street, Birmingham 3 (January 12).

Profwssor of PHYslology - The Secretary, Queen's University, Belfast (January 17).

LECTURER IN DIPLOMA MATHEMaTics (Post Matric. standard), a LeOTURER in PHYsical, ORganic, InORganio and INDUSTrial CHEMISTRY and CHEMICAT ENGINERRING, a LECTURER IN DIPLOMA PHysios (Post Matric. standard), a LROTURER IN ELECTRICAL ENGTNEERING, a LECTURRR IN MECHANICAL ENGINEERING, and a LECTURBR IN CIVIL ENGINERRING, in the Technical Education Branch of the Department of Public Instruction of New South Wales-The Official Secretary, New South Wales Government Offices, 56-57 Strand, London, W.C.2 (January 25).

London, W.C.2 (January 25). tary, Ministry of Agriculture and Fisheries, 23-25 Soho Square, London, W.1 (January 31).

LEOTURER IN GEoLOGY-The Registrar, University College, Hull (January 31).

ASSAYKR OR CHEMIST with special experience in the analysis of non-metallic and metalliferous minerals The Sccretary, Mianrai, Teoranta, Four Provinces House, Harcourt Street, Dublin.

LEOTURER IN HISTOLOGY and a LEOTURER IN BIOCHWMISTRY-The Registrar, King's College, Newcastle-upon-Tyne.

ASSISTANT CHIEF PHARMAOIST by the Government of Malayan Union for Medical Department, Singapore-The Crown Agents for the Colonies, 4 Millbank, London, S.W.1, quoting M.N.18288.

RESEARCH WORKER (Junior, temporary) IN CHEMOTHERAPY AND TROPICAL MEDICINE at the National Institute for Medical ResearchThe Secretary, Medical Research Council, 38 old Queen Street, London, S.W.1.

M.FTALLURGIST by the Ceylon Government for the Department of Commerce and Industries-The Crown Agents for the Colonies, 4 Millbank, London, S.W.1, quoting M.N. 14681.

\section{REPORTS and other PUBLICATIONS (not included in the monthly Books Supplement)}

Great Britain and Ireland

British Rubber Producers' Research Association. Publication No. 75: Dielectric Relaxation and Viscosity of Long-Chain Dipolar Liquids. By Adolf Schallamach. Pp. 14. Publication No. 77: A Differential Fourier Method for Refining Atomic Parameters in Crysta Structure Analysis. By A. D. Booth. Pp. 6. Publication No. 78: The Accuracy of Atomic Co-ordinates derived from Fourier Series in X-Ray Structure Analysis. By A. D. Booth. Pp. 16. (London : British Rubber Producers' Research Association, 1946.) Harry Lindsay, to the Board of Governors. Pp. 80. (London : Imperia]

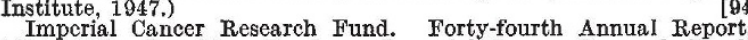
1946-1947. Pp. 36. (London: Imperial Cancer Research Fund 1947.)

\section{Other Countries}

Commonwealth of Australia: Council for Scientific and Industrial Research. Bulletin No, 197: The Analysis of the Hydrocarbon Gases by Fractional Distillation, with especial reference to Cracked Tar Gases. By R. J. L. Martin. Pp. $36+4$ plates. (Melbourne: Government Printer, 1946.)
[213 Pp 234. (Paris: Muśé de l'Homme, 1946) 300 franco. Pp. 234. (Paris: Musée de l'Homme, 1946.) 300 francs, [213 $-65^{\circ}$, from Photographs taken at the Sydney Observatory, Now South Wales, Australia. Vol. 18, with Plate Constants for Vols. 21 to 24 : R.A. $6 \mathrm{~h}$ to $12 \mathrm{~h}$, Dec. $-55^{\circ}$ to $-57^{\circ}$, Plate Centres Dec. $-56^{\circ}$. Pp. viil +119 . Vol. 20 : R.A. $18 \mathbf{h}$ to $24 \mathrm{~h}$, Dec. $-55^{\circ}$ to $-57^{\circ}$, Plate Centres Dec. $-56^{\circ}$. Pp. iv +33 . (Sydney : Governmen

Printer, 1946.) Report of the Secretary of the Smithsonian Institution and Financia Year ended June 30, 1946. (Publication 3864.) Pp. ix +134 . (WashYear ended June 30,1946 . (Publication 3864.$)$ Pp. ix +134 . (Wash-
ington, D.C . Government Printing Oflice, 1946.) 35 cents. [213 ington, D.C '. Government Printing Oflice, 1946.) 35 cents. [213 beetles of the Genus Epilachna (Sens. Lat.) in Asia, Europe and Ausbeetles of the Genus Epilachna (Sens. Lat.) in Asia, Europe and Australia. By G. H. Dieke. (Publication 3860.) Pp. iii $+183+27$ plates.
(Washington, D.C.: Smithsonian Institution, 1947.) (Washington, D.C. : Smithsonian Institution, 1947.) 50 : The Birds of North and Middle America. Commenced by the late Robert Ridgway, continued by Herbert Friedmann. Part 10 . late Robert Ridgway, continued by Herbert Friedmann. Part 10 1946.) 1.25 dollars. 